УДК 78.071.22

DOI https://doi.org/10.31723/2524-0447-2021-32-2-15

\author{
Олег Павлович Бадалов \\ ORCID: 0000-0002-2706-1458 \\ кандидат мистеитвознавства, \\ старший викладач кафедри теорії, історії і практики культури \\ Чернігівської філії \\ Національної академії керівних кадрів культури і мистецтв \\ oleg.p.badalov@gmail.com
}

\title{
ЖИТТЕТВОРЧІСТЬ ОЛЕНИ ГІЛЕЛЬС У КОНТЕКСТІ КУЛЬТУРНОГО ПРОСТОРУ ДРУГОЇ ПОЛОВИНИ ХХ СТОЛІТТЯ
}

Мета публікації - вивчення життєтворчості піаністки, представниці музичної династії Гілельс, заслуженої артистки РФ Олени Еміліівни Гілельс (1948-1996), з'ясування ї̈ внеску у формування музичних феноменів сучасності. Автор досліджує життетворчість О. Гілельс у контексті ї̈ виконавської діяльності як піаністки-солістки, учасниці камерних ансамблів, активної діячки світового фортепіанного руху другої половини XX cm. Методологія статmі грунтується на історико-хронологічному, джерелознавчому, логіко-узагальнюючому методах для аналізу періодичних джерел, архівів родини піаністки, ї̈ творчої біографії, виявлення факторів впливу ї творчості на розвиток культурного простору. Наукова новизна публікації полягає у досліджсенні життетворчості однієї з визначних діячок фортепіанної культури другої половини XX cm. як комплексного феномену, що розвивався у соціокультурному контексті часу. Висновки. Провідною формою творчої діяльності Олени Гілельс, починаючи з кіния 1960-х рр., була концертна робота, що тривала у вітчизняному музичному просторі та була включена у світовий культурний рух. Здобувши освіту у провідних представників Московської фортепіанної школи періоду ї̈ найвищого розквіту, Олена Гілельс здійснювала вагомий внесок у розвиток фортепіанного руху, виступаючи на теренах СРСР, а також гідно репрезентувала досягнення вітчизняного фортепіанного виконавства у численних закордонних турне. Найвищими мистецькими звершеннями, завдяки яким творчість Олени Гілельс увійшла до скарбниці світового музичного мистецтва, є інтерпретація творів В. А. Моцарта та Ф. Шуберта для двох роялів та фортепіано у чотири руки, зафіксована у аудіозаписах. Свідченням значного авторитету, яким користувалась у світовому культурному просторі О. Гілельс, є ї̈ гастрольна діяльність чи не у всіх країнах Свропи, США, Японії та ін. Різностильовий репертуар, наявні технічні мохливості щодо реалізації виконавських ідей висували Олену

(с) Бадалов О. П., 2021 
Гілельс на передній край фортепіанного виконавства кіния $X X \mathrm{~cm}$., але з незалежних від неї причин та у зв'язку з раннім уходом з життя вона не посіла того місия у вітчизняному культурному просторі, на яке заслуговувала.

Ключові слова: О. Гілельс, репертуар, виконавство, фортепіанний дует, гастрольна діяльність, Московська фортепіанна школа.

Badalov Oleg Pavlovich, Ph.D. in Art Criticism, Senior Lecturer at the Department of Theory, History and Practice of Culture of the Chernihiv Branch of the National Academy of Managerial Staff of Culture and Arts

Life creativity of Elena Gilels in the context of the cultural space of the second half of the $20^{\text {th }}$ century

The purpose of the publication is to study the life creativity of the pianist, a representative of the musical dynasty Gilels, Honored Artist of Russia Elena Emilevna Gilels (1948-1996), to clarify her contribution to the formation of modern musical phenomena. Author explores the life of $O$. Gilels in the context of her performance as a pianist-soloist, member of chamber ensembles, an active figure in the world piano movement of the second half of the $20^{\text {h }}$ century. The methodology of the article based on historical-chronological, source-study, logical-generalizing methods for analysis of periodical sources, personal archives of the pianist's family, her creative biography, identification of factors influencing her work on the development of cultural space. The scientific novelty of the publication lies in the study of the life of one of the prominent figures of piano culture of the second half of the $20^{\text {h }}$ century as a complex phenomenon that developed in the socio-cultural context of the time. Conclusions. The leading form of $O$. Gilels' creative activity was concert work, which lasted in the domestic music space, was included in the world cultural movement since the late 1960's. O. Gilels made a significant contribution to the development of the piano movement, performing in the USSR, as well as worthily represented the achievements of domestic piano performance in numerous foreign tours. The highest artistic achievements, thanks to which the work of $O$. Gilels entered the treasury of world music, is the interpretation of works by Mozart and Schubert for two pianos and piano four hands, performed and recorded in audio recordings. Evidence of the considerable authority enjoyed by $O$. Gilels in the world cultural space is her touring activity in almost all European countries, the United States, Japan and others. Diverse repertoire, available technical capabilities for the implementation of performance ideas put $O$. Gilels at the forefront of piano performance of the late $20^{\text {h }}$ century. But for reasons beyond her control and due to early death, she did not take that place in the domestic history of piano performance, which she deserved.

Key words: O. Gilels, repertoire, performance, piano duet, touring activity, Moscow Piano School. 
Актуальність теми дослідження. Сучасне мистецтвознавство та культурологія акцентують значну увагу на дослідженні життєтворчості митця в контексті культуротворення. При цьому «проблема «митець - культурний простір» продовжує й надалі акумулювати не лише енергію творчості, а й синергію наукового пошуку» [3, с. 47]. Саме тому культурологи та мистецтвознавці наполягають на «введенні до наукового обігу нових імен та подійного порядку явищ духовного життя» [1, с. 3]. Серед таких імен - Олена Еміліївна Гілельс (1948-1996) - солістка Московської державної філармонії, заслужена артистка РФ, доцент Московської державної консерваторії ім. П. Чайковского та Моравського університету (Чехія), піаністка, відома широкому загалу, передусім, виступами у середині 1970-х рр. у складі фортепіанного дуету разом 3 видатним митцем, народним артистом СРСР, Героєм Праці, лауреатом Державних премій Емілем Григоровичем Гілельсом, а у теперішній час - забута. Між тим, в останній третині XX ст., вона була однією з провідних піаністок нової генерації, представники якої вийшли на національну та світову сцену наприкінці 1960-х рр. Надзвичайно швидко О. Гілельс здобула визнання як солістка та ансамбліст у країнах так званого «золотого трикутника» (Франція, США, Японія), що відкрило перед нею двері усіх престижних концертних залів світу. Іїі по праву вважали продовжувачем виконавської школи Еміля Гілельса, але стагнація культурного життя та його комерціалізація у період становлення незалежних держав - колишніх республік СРСР, геополітичні та соціокультурні умови розвитку суспільства у той період, а також певна ситуація замовчування, яка була створена навколо родини Е. Гілельса московським музичним істеблішментом у 1980-х - на початку 1990-х pp., значно уповільнили рух піаністки до числа лідерів музичного мистецтва кінця XX ст., а завершення iї життєвого шляху у 1996 р. унеможливило цей процес й, зрештою, спричинило забуття іiі мистецьких звершень. Актуальність статті обумовлена відсутністю наукових досліджень життєтворчості Олени Гілельс, що стає особливо помітним після чверті століття, що минуло від дня іiї смерті 17 червня 1996 р. Сдиною спробою узагальнення творчого спадку мисткині $є$ нарис Т. Голланд [5]. Виданий 2010 р., він представляє собою декілька ескізів про піаністку, що грунтуються, здебільшого, на статтях М. Ігнатьєвої [7; 8] та особистих, не завжди достеменних, спогадах авторки. 
Мета дослідження - вивчення музичної діяльності піаністки О. Гілельс у контексті розвитку культурного простору другої половини XX ст.

Наукова новизна публікації полягає у першому у вітчизняному музикознавстві дослідженні життєтворчості Олени Гілельс на підгрунті невідомих матеріалів приватного архіву родини Гілельс.

Виклад основного матеріалу. Олена Еміліївна Гілельс народилася 5 вересня 1948 р. у Москві. Якщо ім'я іiі батька, творчість якого була предметом вивчення ще за його життя, не потребує представлення, то дослідження мистецького спадку іiі матері Фарізет Алмахситівни Гілельс-Хуцистової (1924-1998), що включає композиторську творчість та вагому за інформативністю мемуаристику, розпочато лише у 2020 р. [2]. Перші уроки фортепіанної гри Олена отримала від матері - випускниці композиторського факультету Московської державної консерваторії ім. П. Чайковського (далі МДК). Про професійну музичну кар'єру доньки батьки не замислювалися. Поштовх до фахової спрямованості музичних занять Олена Гілельс отримала, як не дивно, від Людмили Наумівни Гінзбург (1916-2001), яка була у надзвичайно дружних стосунках з родиною Гілельс, знала Еміля Григоровича ще з часу навчання в Одеській консерваторії та асистентурі-стажуванні у класі Г. Г. Нейгауза. За спогадами чоловіка Олени Гілельс доктора фізико-математичних наук, професора Петра Порфировича Никитенка, який був особисто знайомий з Л. Гінзбург, «під час приїздів до Москви вона зупинялася у готелі біля будинку, де мешкали Гілельси, й проводила у них багато часу. Інколи іiі візити співпадали з багатомісячними відрядженнями Еміля Григоровича, й Фарізет мала змогу приділяти гості з Одеси багато уваги. Осторонь їх спілкування не залишалася донька піаніста, з якою Л. Гінзбург грала на роялі у музичні забавки, акомпанувала елементарним мелодіям, які дівчинка імпровізувала за клавіатурою. Людмила Наумівна з'ясувала, що Олена має абсолютний музичний слух, надзвичайно швидко запам'ятовує музичні мотиви, ритми, вправно повторює за нею на клавіатурі послідовності, має придатну для фортепіанної гри анатомію кисті. Мені особисто довелося опікуватися Людмилою Наумівною, коли вона їздила до Фінляндії з майстер-класами. На прохання Еміля Григоровича, який, до речі, сприяв отриманню запрошення з Фінляндії для 
Л. Гінзбург, я відвозив ії на вокзал, й був з нею, поки вона не сідала у потяг. Під час очікування вона ділилася спогадами про дитинство моєї дружини, розповідала про своє невдоволення, яке висловлювала батькам Олени з приводу того, що вони не поспішають віддавати іiі до музичної школи. А Олена тоді захоплювалася балетом, класичною хореографією, і усі думки та дії було спрямовано у танцювальну сферу. А коли музика перемогла і Олена почала здобувати свої перемоги, Людмила Наумівна, відчуваючи свою причетність до іiі перших кроків у фортепіанному мистецтві, завжди дзвонила і вітала Еміля Григоровича та Фарізет Алмахситівну» [12, арк. 35].

Успадкувавши надзвичайне музичне обдарування від батьків, Олена яскраво проявила його під час навчання у Центральній музичній школі (далі - ЦМШ) при МДК. Її викладачем з фаху була відомий дитячий педагог, заслужений учитель РФ Тамара Олександрівна Бобович (1906-1974), яка, за характеристикою О.Б. Гольденвейзера, була «одним з найцінніших викладачів школи, що працювала в ній від дня заснування $<\ldots>$ За довгі роки роботи Тамара Олександрівна виховала ціле сузір'я першокласних піаністів» [6, с. 7]. О. Гілельс надзвичайно любила свою першу вчительку, зберігала все життя приязні спогади про заняття з нею. Маленьким родинним святом став виступ Олени у звітному концерті класу Т. Бобович 12 лютого 1956 р. у Малому залі МДК, де вона виконала Andantino A. Хачатуряна та дві п'єси 3 «Дитячого альбому» П. Чайковського.

За свідченням О. Гілельс, у дитинстві батько «зовсім не займався зі мною, «я не педіатр», - казав він. Уся моя музика проходила повз нього. Але коли я трохи подорослішала, він став прислухатися до моїх занять» [7, с. 8]. Усвідомлюючи перспективу розвитку музичного обдарування Олени, Еміль Григорович вирішив перевести доньку до класу викладача 3 досвідом концертно-конкурсної діяльності. Розпитавши колег, він почув гарні відгуки про Віру Василівну Горностаєву (1929-2015), яка викладала у Музично-педагогічному інституті ім. Гнесіних, була лауреатом Міжнародного конгресу студентів у Чехословаччині (1950) та солісткою Московської філармонії (1957). За свідченням П. Никитенка, зателефонувавши В. Горностаєвій, Еміль Григорович спитав їі, чи не погодиться вона займатися з його донькою. Віра Василівна відповіла, що згодна, але вона не працює у консерваторії та іiі 
підрозділах. Е. Гілельс запевнив іï, що вирішить це питання [12, арк. 48]. Як відомо, у МДК В. Горностаєва почала викладати з 1959 р. [11]. Згадуючи про той період у своєму житті Віра Василівна зазначала, що «своїх учнів обожнювала, займалася 3 ними з ранку до ночі мов ненормальна» [10, с. 4]. Результати не забарилися; наполеглива робота з В. Горностаєвою, консультації з боку батька, спілкування з визначними митцями фортепіанного виконавства сприяли швидкому музичному розвитку Олени.

У родинному архіві Гілельсів збережено відомості про концерти Олени часу навчання у ЦМШ, з яких привертає увагу виступ 11 грудня 1961 р. У той день відбувся звітний концерт учнів класу В. Горностаєвої, де Олена виконала першу частину Концерту № 1 Ф. Шопена [4, арк. 98]. Дослідниця творчості Е. Гілельса О. Федорович вважає, що підготовка Оленою цього твору не могла проходити поза увагою батька, який потім втілив ідеї, що народилися при спілкуванні 3 донькою під час роботи над концертом, у своєму виконанні цього твору [18, с. 311]. Зазначимо, що у 1961 р. гастрольний графік Е. Гілельса не був занадто інтенсивним, європейські закордонні турне були короткотривалими, тож, перебуваючи у Москві довше, ніж зазвичай, він мав змогу консультувати доньку, акомпанувати їй партію оркестру на другому роялі тощо. До того ж, вперше шопенівський ор. 11 Е. Гілельс виконав 28 вересня 1962 р. у Петрозаводську, тож О. Федорович, вірогідно, має рацію.

Свої студентські роки Олена Гілельс провела у класі народного артиста СРСР, професора Якова Володимировича Флієра (1921-1977) - видатного піаніста та педагога. Час навчання в його класі позначився значним накопиченням репертуару, вагомими здобутками у концертній діяльності на теренах СРСР, у країнах Західної Європи та США. Продовжуючи тему освіти О. Гілельс, варто згадати їі асистентуру-стажування у Ленінградській консерваторії ім. М. Римського-Корсакова протягом 1976-1979 рр. у класі народного артиста СРСР, професора Павла Олексійовича Серебрякова (1909-1977), а після його смерті, у класі заслуженої артистки РФ, професора Галини Петрівни Федорової (1925).

Олена поступила до асистентури по прошесті п'яти років після закінчення МДК, маючи значний виконавський досвід та ім'я у музичному світі; перебування у асистентурі надавало 
перспективу викладацької діяльності у консерваторії. За свідченнями завідувача фортепіанного відділу Середньої спеціальної музичної школи при Санкт-Петербурзькій консерваторії ім. М. Римського-Корсакова В. В. Суслова - очевидця iii репетицій напередодні іспиту, - це була цілком сформована мистецька особистість: На вступному іспиті з фаху Олена грала Прелюдію та фугу сі мажор з першого тому ДТК, Третю сонату Прокоф'єва та «Дитячі сцени» Шумана. Павло Олексійович (Серебряков - O.Б.) на репетиції був присутній, й пам'ятаю його коментар: «Як добре прослідковується почерк Еміля». <...> Можна було розгледіти, прослухати іiі гру в якомусь сенсі під лупою <..>> В іiї грі звертала на себе увагу повна відсутність зовнішніх ефектів, що було в найвищій мірі властиво грі іiі батька» [16, арк. 3].

Відповідь на закономірне питання, чому О. Гілельс не продовжила навчання у Москві й чому була зроблена п'ятирічна пауза між закінченням консерваторії та вступом до асистентури, лежить поза площиною музичного мистецтва. Обставини подій 1971 р. висвітлено у спогадах Ф. А. Гілельс-Хуцистової: «Олена склала усі іспити на п'ятірки в аспірантуру. Здавалося б... Але тут Свєшніков (ректор МДК у 1948-1974 рp. - О.Б.) зіграв «liederabend». Щойно вивішено вдруге новий список, де немає прізвища Гілельс. Було і немає. В чому справа? Відповідь: «Виявили, що у Олени ще на третьому курсі була трійка по політекономії і марксизму-ленінізму» (!?). Так, ця причина призвела нас у стан шоку. Свєшніков! Служитель муз і Старої Площі (місие знаходження будівлі Центрального комітету Комуністичної партії Радянського Союзу - О.Б.). Відзначився. Це подвиг. Гідний заохочення! А? Вдома безвихідь. Соромно за брехню, тільки що народжену. Нарешті Міля зважився. Дзвонить просто Серебрякову до Ленінграду» [4, арк. 197].

На початку 1970-х рр. вже набирала обертів тенденція цькування Еміля Гілельса владою, зокрема, невдоволення викликала його відмова бути після 1970 р. головою журі конкурсу ім. П. Чайковського, його позиція щодо непідписання колективних листів з осудом або певних особистостей, або подій суспільно-політичного життя тощо. Засобом приборкування «норовливого» піаніста було обрано вступну кампанію його доньки - єдине слабке місце Е. Гілельса. I митець, який ніколи не просив за себе, «зважився», як пише його дружина, подзвонити ректору Ленінградської консерваторії, 
своєму другові П. Серебрякову. Незважаючи на його згоду взяти Олену Гілельс до свого класу, час було втрачено, адже вступні іспити завершилися. До того ж, на кілька років уперед було розписано графік гастролей Олени, що й обумовило вступ до асистентури у 1976 р.

Професійна концертна діяльність О. Гілельс розпочалася напередодні закінчення навчання у ЦМШ й тривала тридцять років. За цей час вона об'їхала з концертами весь СРСР, здобула визнання у Франції, США, Японії, гастролювала у майже всіх європейських країнах, Турції, Таїланді, Аргентині, Новій Зеландії. Розглянемо основні віхи ії виконавського шляху.

Перший виступ О. Гілельс на філармонійній сцені відбувся 27 січня 1966 р. у Свердловську (тепер - Скатеринбург), де вона зіграла Рапсодію на тему Паганіні С. Рахманінова у супроводі симфонічного оркестру на чолі з М. Паверманом, який у своїх мемуарах зазначив, що Олена твір «виконала блискуче» [13, с. 173].

За межами СРСР О. Гілельс вперше виступила 16 серпня 1967 р. на Сьомому Міжнародному фестивалі у французькому місті Ментон. Її сольна програма включала Чакону соль мажор Г. Генделя, Арабеску та Варіації на тему Клари Вік Р. Шумана, Іспанську рапсодію Ф. Ліста, Сонату № 3 С. Прокоф'єва та ін.

Взимку 1969 р. відбулися концерти Олени у США. 16 лютого піаністка дебютувала у «Карнегі-Холл» 3 Концертом № 1 П. Чайковського. Про іiі виконання рецензент газети «The New York Times» Д. Хенахан зазначив, що «у такому чоловічому репертуарі, навіть зважаючи на сучасну емансипацію, тинейджер Олена Гілельс витримала боротьбу проти цього монстра» [20, с. 28]. Вдруге О. Гілельс мала успіх у Нью-Йорку з сольною концертною програмою у січні 1977 р. [19, с. 19].

Надзвичайно важливим для творчої біографії О. Гілельс був 1972 р. Подією у світовій моцартіані став ii виступ у дуеті з батьком 30 серпня на закритті Зальцбургського фестивалю, де вони виконали Концерт № 10 мі бемоль мажор для двох фортепіано К. 365 В. А. Моцарта у супроводі Віденського філармонійного оркестру під орудою Карла Бьома. За характеристикою О. Федорович, це був «істинно гілельсовський Моцарт, який і раніше визначали як диво. Але тепер це диво зазвучало на двох роялях. По-гілельсовськи там усе: шляхетне 
звучання, неймовірна майстерність, висока простота, проникливість інтонації» [18, с. 312].

15-30 листопада 1972 р. О. Гілельс взяла участь у Третьому Міжнародному конкурсі у Монтевідео. Це був перший виїзд радянської групи піаністів до столиці Уругваю. Незважаючи на іронічну характеристику В. Горностаєвої - «банановий конкурс», яку наводить П. Нікітенко [12, арк. 92], це змагання було досить важким, про що свідчить програма, представлена Оленою: Ф. Мендельсон. Серйозні варіації, С. Прокоф'єв. Соната № 3 (перший тур); I. С. Бах. ДТК, I том, Прелюдія та фуга № 24 сі мінор, Ф. Шопен. Етюд соль бемоль мажор ор. 10 № 5, Ф. Ліст Етюд фа мінор № 10 з «Трансцендентних етюдів», К. Дебюссі. Етюд «Кварти» № 3 з 12 етюдів (другий тур); В. А. Моцарт. Фантазія К. 396, Л. Бетховен. Соната № 21, Р. Шуман. «Крейслеріана», А. Хачатурян. Токата (третій тур); Л. Бетховен. Концерт № 3 (четвертий тур). Першу премію журі поділило між Володимиром Бакком (клас Я. Зака) і Юрієм Слєсарєвим (клас В. Мержанова). Олена Гілельс, яка на той час не належала до класу будь-якого професора, була удостоєна звання лауреата П'ятої премії.

Двічі піаністка гастролювала у Японії. У квітні 1978 р. вона дала дев'ять сольних концертів (Р. Шуман. «Крейслеріана», Ф. Мендельсон. Серйозні варіації, Ф. Ліст. Іспанська рапсодія, С. Прокоф’єв. Сонатина та Соната № 2, М. Мусоргський. «Картинки з виставки»). У 1991 р. О. Гілельс виступила у 12 містах як 3 сольними програмами (Л. Бетховен. 15 варіацій з фугою, Ф. Шуберт. Експромти, Р. Шуман. Арабеска, «Крейслеріана», П. Чайковський. Тема з варіаціями ор. 19 № 6, С. Рахманінов. Шість прелюдій), так і з симфонічним оркестром (Л. Бетховен. Концерт № 5).

У 1986 р. $з$ нагоди 70-річчя від дня народження Е. Гілельса Олена дала концерти у Брюсселі, Антверпені та Москві. Наприкінці 1980-х - у першій половині 1990-х pp. піаністка гастролювала в Іспанії, Нідерландах, Чехії [7, с. 8].

Указом Президії Верховної Ради РРФСР від 8 липня 1991 р. «Про присвоєння почесних звань РРФСР працівникам мистецтва» солістка Московської державної філармонії Олена Гілельс за заслуги в галузі радянського мистецтва була відзначена званням «Заслужений артист РРФСР» [17, с. 987].

9 квітня 1995 р. у Великому залі МДК відбувся останній московський концерт Олени Гілельс, де прозвучали Сонати 
№№ 8, 17 Л. Бетховена, «Дитячі сцени» Р. Шумана, Соната № 2 С. Прокоф’єва.

Вивчення особистого архіву Олени Гілельс засвідчило систематичну роботу піаністки над сольним концертним репертуаром. Щороку у ньому з'являлися нові твори (зазначено найвагоміші): 1968 р. - Концерт № 1 П. Чайковського, Концерт № 3 Л. Бетховена; 1970 р. - «Крейслеріана» Р. Шумана; 1971 р. - Сонати №№ 17, 21, 30 Л. Бетховена, Фантазія Ф. Шопена; 1974 р. - Концерт № 27 В. А. Моцарта; 1975 р. Балада № 2, Скерцо № 2 Ф. Шопена; 1978 р. - Рондо для фортепіано з оркестром В. А. Моцарта, Концерт соль мажор И. Гайдна; 1979 р. - Концерт Р. Шумана; кінець 1970-х рр. «Картинки з виставки» М. Мусоргського; 1981 р. - Концерт № 23 В. А. Моцарта; 1984 р. - 15 варіації з фугою, Соната № 32 Л. Бетховена; 1985 р. - Сонати №№ 12, 18, 26 Л. Бетховена; 1986 р. - Соната № 3 Ф. Шопена; 1989 р. - Концерт № 2 П. Чайковського; 1990 р. - Фантазія «Скиталець» ор. 15 Ф. Шуберта, Тема з варіаціями ор. 19 № 6 П. Чайковського, Концерт № 5 Л. Бетховена; 1991 р. - Концерт № 26 В. А. Моцарта [9].

Значна кількість творів великої форми у репертуарі О. Гілельс сприяла iї співпраці з визначними диригентами: Є. Свєтланов, В. Федосеєв, В. Синайський, В. Дударова, С. Сондецкіс, Т. Зандерлінг, К. Бьом, 3. Мета, Л. Маазель, П. Ардженто, С. Одзава та ін.; вона грала з Віденським філармонійним оркестром, Оркестром національної академії «Санта Чечилія», Бельгійським національним оркестром, Моцартеум-оркестром, Бостонським оркестром.

Серед сольних концертних програм Олени Гілельс, що користувалися найбільшим успіхом у публіки, можна виокремити монографічні програми з творів Бетховена (Сонати №№ 14, 17, 21, 30) та Р. Шумана (Соната № 2, «Дитячі сцени», «Крейслеріана», «Вранішні пісні» ор. 133). Нікого не залишали байдужими програми фортепіанного дуету Олени та Еміля Гілельсів, що включали твори Ф. Шуберта. Серед партнерів О. Гілельс у камерно-інструментальному виконавстві були Державний струнний квартет імені Бетховена (Фортепіанний квінтет «Форель» Ф. Шуберта), бельгійський ансамбль «Арабеск» (фортепіанні квартети В. А. Моцарта К. 478, К. 493, фортепіанний квартет № 1 Й. Брамса), знана болгарська піаністка Мілена Моллова (твори Ф. Шуберта для фортепіано у чотири руки). 
Виконавське мистецтво Олени Гілельс збережено у аудіозаписах, здійснених як професійними студіями, так і поціновувачами-любителями. Першим з них став запис фірмою «Мелодія» концерту Державного академічного симфонічного оркестру під керівництвом С. Свєтланова від 20 лютого 1968 р., де Олена виконала Концерт № 1 П. Чайковського.

Найвідомішим записом О. Гілельс є диск з Концертом № 10 для двох фортепіано В. А. Моцарта (разом з Віденським філармонійним оркестром на чолі з К. Бьомом) та Фантазією фа мінор ор. 103 Ф. Шуберта у ансамблі з Емілем Гілельсом (партія другого фортепіано), який перевидається щороку від часу його запису у 1973 р. німецьким аудіолейблом «Deutsche Grammophon $\mathrm{GmbH».} \mathrm{Про} \mathrm{високий} \mathrm{виконавський} \mathrm{рівень}$ цих записів свідчить факт їх тиражування на одному диску з Концертом № 27 сі бемоль мажор К. 595 В. А. Моцарта у виконанні Е. Гілельса, що досі входить до списку «50 кращих записів Моцарта в історії» [21]. У 1979 р. фipма «Polydor International $\mathrm{GmbH»} \mathrm{здійснила} \mathrm{запис} \mathrm{творів} \mathrm{Ф.} \mathrm{Шуберта} \mathrm{для}$ фортепіано у чотири руки у виконанні Олени (перша партія) та Еміля (друга партія) Гілельсів: Andantino с варіаціями сі мінор ор. 84 №1, Велике рондо ля мажор ор. 107, Фантазія фа мінор ор. 103, Шість екосезів з ор. 18-а (реліз диску відбувся i у СРСР). У 1980 р. фірма «Мелодія» видала диск «Елена Гилельс играет Шумана: Детские сцены ор. 15, Арабески op. 18, Quasi variation: вариации на тему Andantino Клары Вик из Сонаты № 3 фа минор ор. 14 (3 ч.), Р. Шуман - Ф. Лист. Посвящение ор. 25 № 1». Уявлення про камерно-інструментальне виконавство Олени Гілельс дає підготовлений разом 3 японською скрипалькою Куніко Нагатою диск з записами творів П. Чайковського для скрипки і фортепіано, виданий у Бельгії у 1992 p.

Оглядовий аналіз записів Олени Гілельс дозволяє стисло, шо обумовлено обсягом статті, узагальнити основні риси іiі виконавського стилю. О. Гілельс мала досконало розвинений піаністичний апарат, завдяки чому вирішувала технічні задачі найвищої складності. У центрі ії виконавського буття твори В. А. Моцарта, Л. Бетховена, Р. Шумана, П. Чайковського. Звуковий ідеал піаністки народжений на межі пізнього класицизму і раннього романтизму, що обумовило іiі туше - чітке, прозоре, з відчуттям кожного звуку, позбавлене надмірної педалізації, що дозволяло ніби поліфонізувати 
музичну тканину, виокремлювати підголоски, певні відгалуження музичних ліній. Виконавському почерку О. Гілельс властиві лаконічність висловлювання, увага до найменших деталей тексту, чітка артикуляція, контроль емоцій навіть у найбурхливіших творах, коли кожна нота інтонується як складова частина мелодійного руху, а не загальної моторики; багата динамічна палітра, завдяки чому ïi forte-fortissimo залишається у межах «співаючого (не ударного)» рояля, а для iï piano-pianissimo властиве тонке філірування звуку.

Останні роки життя, окрім виконавської діяльності, Олена Гілельс займалася педагогічною роботою. У 1989 р. вона стала викладати на кафедрі камерного ансамблю МДК. За спогадами одного з іiі студентів, Олена Гілельс проводила «чудові уроки з камерного ансамблю у консерваторії. Скромна, спокійна, високоерудована. Відмінний педагог» [14, арк. 1]. На жаль, тодішнє керівництво консерваторії не вважало за потрібне залучити О. Гілельс до роботи на кафедрі спеціального фортепіано, де б вона - концертуюча піаністка та очевидець творчого методу видатного митця Еміля Гілельса могла передати наступній генерації музикантів набуті знання та досвід. На відміну від московських музичних «менеджерів», кафедра сольного фортепіано Моравського університету, що у чеському місті Острава, запропонувала їй посаду доцента, де вона працювала протягом 1991-1996 рр.: «я прийшла до нового, щойно створеного навчального закладу. Власне кажучи, відкриваю перші сторінки його біографії. Причому, вони одразу створили методичний центр. Оскільки я не методист, а виконавець, я прочитаю декілька лекцій про інтерпретацію німецьких романтиків та російської музики» [7, с. 8].

Висновки. Підбиваючи підсумки дослідження, можемо дійти висновку, що провідною формою творчої діяльності Олени Гілельс була концертна робота, що, починаючи 3 кінця 1960-х рр., тривала у вітчизняному культурному просторі, була включена у світовий музичний рух. Здобувши освіту у провідних представників Московської фортепіанної школи періоду іiі найвищого розквіту, Олена Гілельс здійснювала вагомий внесок у розвиток фортепіанного руху, виступаючи на теренах СРСР, а також гідно репрезентувала досягнення вітчизняного фортепіанного виконавства у численних закордонних турне. Найвищими мистецькими звершеннями, завдяки яким творчість Олени Гілельс увійшла 
до скарбниці світового музичного мистецтва, $є$ інтерпретація творів В. А. Моцарта та Ф. Шуберта для двох роялів та фортепіано у чотири руки, здійснена та зафіксована у аудіозаписах. Свідченням значного авторитету, яким користувалась у світовому музичному русі О. Гілельс, є їі співпраця з провідними диригентами другої половини ХX ст., широка географія гастрольної діяльності чи не у всіх країнах Европи, США, Японії та ін. Окремі епізоди творчого життя О. Гілельс, в тому числі штучно створені перешкоди для іiі педагогічної роботи, що розпочалася у достатньо пізньому віці, можуть слугувати прикладом того тиску адміністративно-командної системи, якого зазнавала радянська інтелігенція періоду так званого «реального (развитого) соціалізму». Різностильовий репертуар (XVII-XX ст.) та наявні технічні можливості щодо реалізації виконавських ідей висували Олену Гілельс на передній край фортепіанного виконавства кінця XX ст., але з незалежних від неї причин та у зв'язку з раннім уходом з життя вона не посіла того місця у вітчизняній історії фортепіанного виконавства, на яке заслуговувала.

Перспективи подалыших досліджень окресленої проблематики полягають у вивченні аудіозаписів піаністки з метою з'ясування рис iіi виконавського стилю у різні періоди творчості; узагальнення потребує педагогічна діяльність Олени Гілельс на кафедрі камерного ансамблю Московської консерваторії та музичному факультеті Моравського університету у чеському місті Острава, що сприятиме подоланню фрагментарності у сприйнятті творчого спадку мисткині, допоможе відтворити їі життєтворчість у всій широті його проявів, збагатить фактичний матеріал з історії вітчизняного фортепіанного виконавства кінця XX ст., виокремить певні факти його впливу на розвиток музичної культури інших країн.

\section{СПИСОК ЛІТЕРАТУРИ}

1. Барсова Л. Роль творческой личности в формировании художественной жизни епохи (на примере жизни и творчества Н. А. Римского-Корсакова и его ближайшего окружения) : автореф. дис. ... Д-ра культурологии: спец. 24.00.01 - теория и история культуры (культурология). Санкт-Петербургский государственный університет, 2007. 43 с.

2. Батагова Т. Фаризет Гилельс-Хуцистова: она была одним из первых осетинских музыкантов-профессионалов. Музыка и время. Москва : Научтехлитиздат, 2020. № 10. С. 10-15. 
3. Виткалов, С., Виткалов, В. Український митець у просторі сучасної культури. Часопис Національної музичної академії України імені П.І. Чайковського. Київ. № 4(49). С. 46-65.

4. Гилельс-Хуцистова Ф.А. Воспоминания // Особистий архів родини Гілельс. Машинопис. Москва, б/д, не пізніше 1990 року. 873 арк.

5. Голланд Т. Елена, дочь Эмиля. Екатеринбург : АМБ, 2010. $80 \mathrm{c}$.

6. Долинская Е. О дорогом учителе. К 100 -летию со дня рождения Тамары Александровны Бобович. Музыкант-Классик. Москва : ИП Русак А.Е., 2006. № 5. С. 7-9.

7. Игнатьева М. Дочерняя судьба. Культура. 1993. 6 ноября. С. 8.

8. Игнатьева М. Преодоление. Культура. 1994. 14 мая. С. 9.

9. Концертный репертуар Елены Гилельс / Особистий архів родини Гілельс. Машинопис. Москва, б/д, не пізніше 1996 року. 5 арк.

10. Меркулов А. Памяти профессора В.В. Горностаевой: «Я всегда делала то, что мне было близко» / Музыкант-классик. Москва : ИП Русак А.Е., 2015. № 1-2. С. 2-8.

11. Московская государственная консерватория имени П. И. Чайковского. Профессорско-преподавательский состав. Горностаева Вера Васильевна. URL: https://www.mosconsv.ru/ru/person. aspx?id=8855 (дата звертання: 15.03.2021).

12. Никитенко П. Воспоминания / Особистий архів родини Гілельс. Машинопис. Москва, 2021 рік. 198 арк.

13. Паверман М. Войти в музыкальный мир: Воспоминания дирижера. Екатеринбург : Издательсво Уральского университета, 1999. 205 c.

14. Свиридов Р. О моём обучении в классе камерного ансамбля Елены Эмильевны Гилельс в 1991-1996 гг. / Особистий архів родини Гілельс. Машинопис. Сидней, 2020. 1 арк.

15. Стенограмма творческой встречи с супругом дочери Э. Г. Гилельса Е. Э. Гилельс доктором физико-математических наук, профессором Петром Порфирьевичем Никитенко в библиотекечитальне им. И. Тургенева, посвящённой 105-летию со дня рождения Э. Г. Гилельса. Москва, 27 апреля 2021 г. / Особистий архів родини Гілельс. Машинопис. Расшифровка К.П. Гилельса. 25 арк.

16. Суслов В. Вспоминая Елену Гилельс. Стенограма творческой встречи 3 вересня 2020 г. / Особистий архів родини Гілельс. Санкт-Петербург. Розшифровка М. Яригіної. 5 арк.

17. Указ Президиума Верховного Совета РСФСР от 8 июля 1991 г. «О присвоении почётных званий работникам искусства». Ведомости Съезда народных депутатов РСФСР и Верховного Совета РСФСР. 1991. 11 июля. № 28. С. 987.

18. Федорович Е., Рэйнор Д., Шварц Ф. Неизвестный Гилельс. Биография. Концертография. Екатеринбург : Уральская государственная консерватория им. М.П. Мусоргского, 2020. 536 с. 
19. Davis P. Elena Gilels in New York Debut as Pianist. The New York Times. 1977. Jan. 24. P. 19.

20. Henahan D. Elena Gilels, 19, Plays Tchaikovsky. The New York Times. 1969. Feb. 17. P. 28

21. The 50 best Mozart albums (2021 update). February 25, 2021. URL: https://www.gramophone.co.uk/features/article/the-50-best-mozart-albums-2021-update_(дата звертання: 12.03.2021).

\section{REFERENCES}

1. Barsova, L. (2007). The role of creative personality in the formation of artistic life of the era (on the example of the life and work of N. A. Rimsky-Korsakov and his immediate environment): thesis dis. ... Dr. of Cultural Studies: 24.00.01 - theory and history of culture (culturology). St. Petersburg State University. 43 pp. [in Russian].

2. Batagova, T. (2020). Farizet Gilels-Khutsistova: she was one of the first professional Ossetian musicians. Music and Time. Moscow: Nauchtekhlitizdat. Issue 10. Pp. 10-15 [in Russian].

3. Vytkalov, S., Vytkalov, V. (2020). Ukrainian artist in the space of modern culture Journal of Tchaikovsky National Music Academy of Ukraine. Kyiv. Issue 4 (49). Pp. 46-65 [in Ukrainian].

4. Gilel's-Hucistova, F. A. (n.d.). Memories. Personal archive of the Gilels family. Typescript. Moscow, not older than 1990. 873 sheets [in Russian].

5. Golland, T. (2010). Elena, daughter of Emil. Yekaterinburg: AMB. 80 pp. [in Russian].

6. Dolinskaja, E. (2006). About a dear teacher. To the $100^{\text {th }}$ anniversary of the birth of Tamara Alexandrovna Bobovich. MusicianClassic. Moscow: Rusak A. E. Issue 5. Pp. 7-9 [in Russian].

7. Ignat'eva, M. (1993). Daughter fate. Culture. November, 6. P. 8 [in Russian].

8. Ignat'eva, M. (1994). Overcoming. Culture. May, 14. P. 9 [in Russian].

9. Concert repertoire of Elena Gilels (n.d.). Personal archive of the Gilels family. Typescript. Moscow, not older than 1996. 5 sheets [in Russian].

10. Merkulov, A. (2015). In memory of Professor V. V. Gornostaeva: "I have always done what was close to me". Musician-classic. Moscow : IP Rusak A. E. Issue 1-2. Pp. 2-8 [in Russian].

11. Moscow State Tchaikovsky Conservatory. Teaching staff. Vera Gornostaeva. (n.d.). URL: https://www.mosconsv.ru/ru/person. aspx?id=8855 (Access mode: 15.03.2021) [in Russian].

12. Nikitenko, P. (2021). Memories. Personal archive of the Gilels family. Typescript. Moscow. 198 sheets [in Russian].

13. Paverman, M. (1999). Enter the musical world: Memoirs of a conductor. Yekaterinburg: Publishing House of the Ural University. 205 pp. [in Russian].

14. Sviridov, R. (2020). About my studies in the chamber ensemble class of Elena Emilievna Gilels in 1991-1996. Personal archive of the Gilels family. Typescript. Sydney. 1 sheet [in Russian]. 
15. A transcript of the meeting with the spouse of E. G. Gilels' daughter E. E. Gilels, Doctor of Physical and Mathematical Sciences, Professor Pyotr Porfirievich Nikitenko in the library-reading room named after I. Turgenev, dedicated to the $105^{\text {th }}$ anniversary of the birth of E. G. Gilels. Moscow, April, 27. Personal archive of the Gilels family. Typescript. Moscow. Decoding by K. P. Gilels. 25 sheets [in Russian].

16. Suslov, V. (2020). Remembering Elena Gilels. Stenogram of the creative meeting on May, 3. Personal archive of the Gilels family. Typescript. Moscow. Decoding by M. Yarigina. 5 sheets [in Russian].

17. Decree of the Presidium of the Supreme Soviet of the RSFSR dated July 8, 1991 "On conferring honorary titles to art workers". Bulletin of the Congress of People's Deputies of the RSFSR and the Supreme Soviet of the RSFSR. 1991. July, 11. Issue 28. P. 987 [in Russian].

18. Fedorovich, E., Rjejnor, D., Shvarc, F. (2020). Unknown Gilels. Biography. Concertography. Yekaterinburg: Ural State Conservatory named after M. P. Mussorgsky. 536 pp. [in Russian].

19. Davis, P. (1977). Elena Gilels in New York Debut as Pianist. The New York Times. Jan. 24 [in English].

20. Henahan, D. (1969). Elena Gilels, 19, Plays Tchaikovsky. The New York Times. Feb. 17 [in English].

21. The 50 best Mozart albums (2021 update). February 25, 2021. URL: https://www.gramophone.co.uk/features/article/the-50-bestmozart-albums-2021-update (Access mode: 12.03.2021) [in English]. 